\title{
Cechy obce i lokalne w średniowiecznej i nowożytnej ceramice elbląskiej. Zarys problematyki na podstawie wybranych przykładów
}

\section{Foreign and local features in mediaeval and modern Elbląg ceramics. Problem outline on the base of selected examples}

Najczęściej przy identyfikacji cech lokalnych i obcych porównywane są wyroby rzemiosła miejscowego oraz z innych ośrodków, niejednokrotnie bardzo odległych, nabywane zazwyczaj w drodze wymiany handlowej. Niekiedy te obce wytwory, cechy, idee przybywały wraz z nowymi osadnikami, w wyniku wymiany handlowej, a także wojen i podbojów. Celem niniejszego artykułu jest wskazanie cech miejscowych i obcych w garncarstwie elbląskim, czytelnych zarówno w wyrobach średniowiecznych, jak i nowożytnych. W przypadku Elbląga, założonego przez kolonistów, bardzo dobrze widoczny jest inny problem - które cechy należy uznać za obce, a które za miejscowe? Jak się okaże w dalszej części wywodu, wszystko zależy od przyjętego punktu widzenia, bowiem co swojskie dla jednej grupy, będzie obce dla innej. Dlatego wydaje się, że bardzo często nie można przeciwstawiać sobie tych cech. W społeczeństwie średniowiecznym, a w dużej mierze także w nowożytnym, to co swojskie i to co obce wzajemnie się uzupełniało, tworząc nową jakość.

W najstarszych jednostkach stratygraficznych odkrytych na Starym Mieście w Elblągu, datowanych od lat 30.-40. do 60.-70. XIII wieku, współwystępują fragmenty naczyń siwych oraz wytwarzanych według tradycyjnych, jeszcze wczesnośredniowiecznych metod i technik (ryc. 1) (Marcinkowski 2006a, s. 273-275). Zbiór uzupełniają również naczynia importowane. W różnych jednostkach wzajemny udział procentowy tych grup wyrobów garncarskich jest bardzo różny. W niniejszych rozważaniach interesują nas jedynie naczynia siwe i tzw. tradycyjne. Udział tych ostatnich w poszczególnych zespołach jest bardzo różny - w niektórych nie występują, w innych ich odsetek waha się od kilku do maksymalnie $20 \%$. Dla najstarszego okresu z historii miasta brakuje źródeł pisanych, które pomogłyby w ustaleniu zamożności mieszkańców poszczególnych 

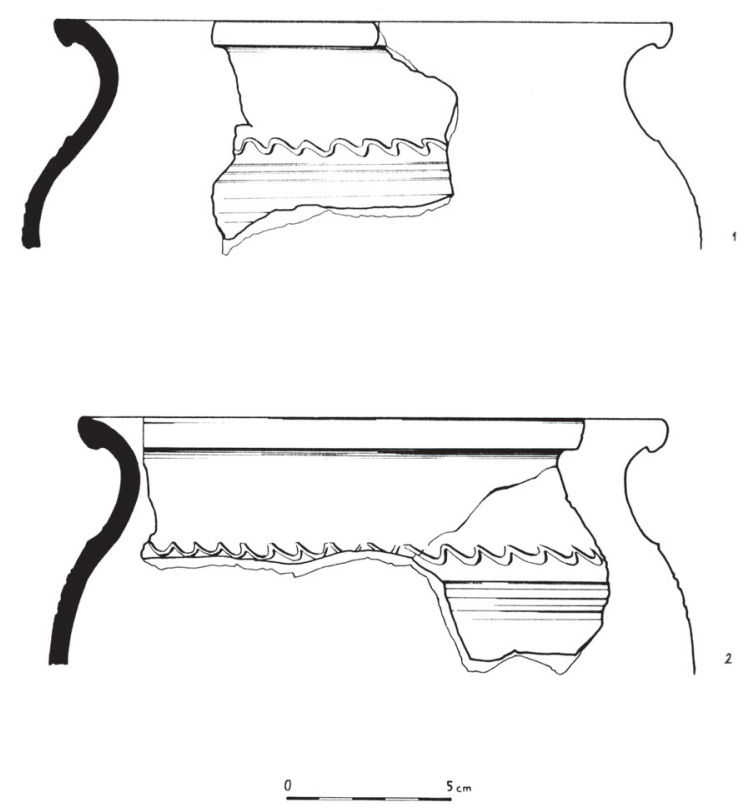

Ryc. 1. Elbląg - Stare Miasto. Fragmenty naczyń tzw. tradycyjnych (rys. B. Kiliński)

Fig. 1. Elbląg - The Old Town. Fragments of vessels, so called traditional (drawing by B. Kiliński)

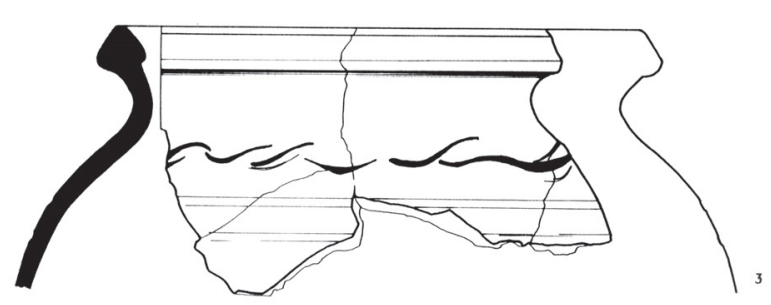

działek. Natomiast na podstawie analizy materiałów archeologicznych można wnioskować, że liczba używanych naczyń wykonanych w tradycyjnej technice nie była uzależniona od zamożności właścicieli i mieszkańców konkretnych działek.

Doskonałym przykładem dla tej tezy jest tzw. dom poławiacza jesiotrów, datowany metodami archeologicznymi i dendrochronologicznymi na około 1250 rok. Pozostałości drewnianego budynku o powierzchni $40 \mathrm{~m}^{2}$ zostały odkryte na parceli nr 23 przy ulicy Bednarskiej, prowadzącej od Starego Rynku w kierunku rzeki (Marcinkowski 2006b). W obrębie pozostałości zabudowy znaleziono między innymi 280 fragmentów ceramiki, z których zrekonstruowano 47 naczyń oraz dwie pokrywki. Najliczniejszą grupę tworzyły wyroby siwe (62,7\%), na drugim miejscu znalazły się naczynia tradycyjne (19,5\%), pozostałą część stanowiły różnorodne naczynia importowane, wśród których były wczesne wyroby kamionkowe, prawdopodobnie z ośrodków nadreńskich, w tym między innymi z Brunssum-Schinveld (Rębkowski 1995, s. 48-49) ponadto czerwona ceramika szkliwiona wytwarzana w rejonie flandryjsko-holenderskim i Danii oraz być 
może w Lubece i północnych Niemczech (Lüdtke 1985, s. 54-59). Znaleziono też fragmenty dzbanów, między innymi z ceramiki czerwonej (niem. roten Irdenware), być może z pracowni garncarskich w Lubece (Lüdtke 1985, s. 59-60) oraz prawdopodobnie z wschodnioangielskich warsztatów ceramicznych (Lüdtke 1985, s. 66; Rębkowski 1995, s. 61-62). Na podstawie asortymentu naczyń można wnioskować, że mieszkaniec tego domu - rybak, specjalizujący się w poławianiu jesiotrów - był osobą zamożną. Przypuszczenie to potwierdzają również znaleziska tkanin - jeden fragment wełnianej, z Flandrii lub Anglii oraz trzy fragmenty delikatnego, ażurowego jedwabiu (Maik 2005). Trudno zatem wnioskować, że używanie naczyń tzw. tradycyjnych zależne było od zasobności materialnej. Podobną sytuację zaobserwowano również w innych zespołach $\mathrm{z}$ tego okresu, w których stwierdzono współwystępowanie naczyń siwych, tzw. tradycyjnych i importowanych z zachodnioeuropejskich ośrodków. Bardziej prawdopodobne jest, że egzemplarze wykonane w tradycyjnej technice stanowiły jedynie swoiste opakowanie zakupionego produktu, być może wykonanego w podelbląskich wsiach, zamieszkałych głównie przez rodzimą ludność pruską. Mogły też być nabywane jako uzupełnienie naczyń kuchennych, ponieważ zapewne oferowano je po niższych cenach niż wyroby elbląskich garncarzy wytwarzających naczynia siwe. W przypadku najstarszych zespołów naczyń ceramicznych można zadać pytanie, które z nich należy lub można uznać za lokalne, a które za obce. Oczywiście jest to uzależnione od przyjętego punktu widzenia - miejscowych Prusów lub przybyłych tutaj osadników budujących nowe miasto w powstającym państwie krzyżackim.

Kolejne współistnienie w Elblągu różnych tradycji garncarskich możemy zaobserwować w asortymencie naczyń powstałym w warsztacie datowanym na 3. ćwierć XIII wieku (Marcinkowski 2003). Pozostałości pieca garncarskiego wraz z warstwą destruktów powstałych w trakcie wypałów zostały odkryte w północno-wschodniej części Starego Miasta, w obrębie miejskich obwałowań. Takie usytuowanie warsztatu garncarskiego miało duże znaczenie, bowiem prawdopodobnie determinowało pochodzenie etniczne garncarza. Zachowane dokumenty korporacyjne z Torunia i Elbląga jednoznacznie podkreślają, że obywatelstwo miejskie było zastrzeżone jedynie dla osób ,języka niemieckiego”. Co prawda są to dokumenty z późniejszego okresu, jednak brakuje przesłanek, które nie pozwoliłyby odnieść tego postanowienia do 2. połowy XIII wieku. Jednocześnie w najstarszym wilkierzu toruńskim z 1300 roku znajduje się wzmianka na temat rzemiosła. Czytamy w niej, że jednostką wytwórczą jest warsztat stanowiący własność mistrza, a mistrzem może zostać jedynie ten, kto posiada obywatelstwo miejskie (Kropidłowski 1977, s. 36-37). Można zatem przyjąć, że garncarz wypalający naczynia w odkrytym piecu był osobą ,języka niemieckiego", osadnikiem wnoszącym pewien niezbędny poziom wiedzy technicznej, organizacyjnej i doświadczenia społecznego. 
Analiza fragmentów naczyń odkrytych w obrębie pozostałości warsztatu pozwoliła na poznanie asortymentu wyrobów wytwarzanych przez elbląskiego garncarza. Możliwe było także sformułowanie przypuszczeń identyfikujących odbiorców naczyń powstających w tym warsztacie. Charakterystyczne jest to, że wszystkie egzemplarze mają wyłącznie płaskie dna, co jest dosyć trudne do wytłumaczenia wobec panującego do niedawna poglądu o masowym napływie osadników z Westfalii i Nadrenii.

Na podstawie niektórych rodzajów naczyń wytwarzanych przez elbląskiego garncarza można wskazać prawdopodobny kierunek pochodzenia przynajmniej części osadników przybyłych do Elbląga w 2. połowie XIII wieku. Bardzo duży udział procentowy (86\%) garnków typu I, z wrębem i okapem, w ogólnej liczbie naczyń pochodzących z pieca wskazuje, że zdominowały one całkowicie zestaw naczyń kuchennych (ryc. 2). Formy te wywodzi się z terenów Górnej Saksonii i Turyngii (Mechelk 1981), natomiast nie są one spotykane na terenach północnoniemieckich. Bezpośrednie nawiązania do wyrobów z Saksonii znajdujemy również w przypadku pucharów, także wykonywanych przez elbląskiego garncarza, choć już w znacznie mniejszej liczbie (Mechelk 1981, s. 78, ryc. 34: 2, tabl. 27). Jedna $z$ form dzbanów, określona w materiale elbląskim jako typ VIII (ryc. 3: 1, 2), posiada swoje bezpośrednie analogie w materiałach $z$ Wrocławia, wśród których znalazły się identycznie ukształtowane i zdobione naczynia (Niegoda 1999, ryc. 16f).

Jednocześnie w tym samym warsztacie powstawały wyroby, które należy łączyć z kręgiem północnoniemieckim. Przede wszystkim są to misy o części brzegowej nachylonej do wewnątrz, podkreślonej ostrym załomem (określone w materiale elbląskim jako typ IV; ryc. 4). Dla tej formy istnieją bezpośrednie odniesienia w materiałach ze stanowisk w Dolnej Saksonii (Janssen 1966, ryc. 7: 25, 26; Stadt Archäologie 1984, ryc. 62: 8). Innym wyrobem garncarskim mającym także bezpośrednie analogie na terenach północnych są lampy oliwne o bardzo charakterystycznej formie - płaska czara umieszczona jest na nodze w kształcie klepsydry z wysoką stopką. Zidentyfikowano je głównie na podstawie materiału ikonograficznego, a odkryto je między innymi w Haithabu (Hübner 1959, tabl. 2), Århus (Madsen 1971, s. 87) i Lubece (Lüdtke 1985, s. 77-79, tabl. 4). Wśród destruktów z pieca odkryto jedynie fragmenty płaskich czar o średnicach wylewów w przedziale 12-20 cm i grubości ścianek powyżej $10 \mathrm{~mm}$ (ryc. 3: 3, 4), natomiast charakterystyczną nogę (stopę) znaleziono podczas badań w innej części miasta.

Na podstawie analizy odkrytych fragmentów naczyń można domniemywać skąd pochodził garncarz i przynajmniej część mieszkańców zamieszkujących Elbląg pod koniec XIII wieku. Garncarz najprawdopodobniej był osadnikiem przybyłym do Elbląga z Turyngii lub Górnej Saksonii, być może poprzez Śląsk. Nie można wykluczyć, że przez jakiś czas pracował właśnie na Śląsku. Po osiedleniu się w Elblągu wytwarzał w większości naczynia o formach, które poznał jeszcze 

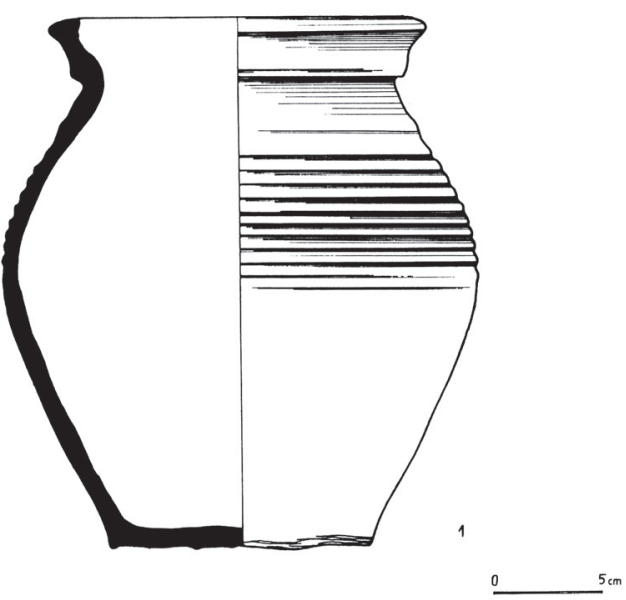

Ryc. 2. Elbląg - Stare Miasto. Garnki z okapem typu I (rys. B. Kiliński)

Fig. 2. Elbląg - The Old Town. Pots with spouts type I (drawing by B. Kiliński)

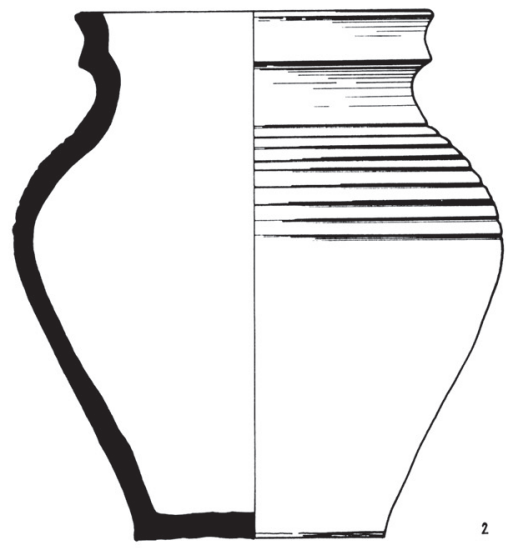

w swoich rodzinnych stronach. Były to również wyroby, które zaspokajały gusty i potrzeby znacznej części mieszkańców miasta. Ta duża grupa nowych obywateli powstającego państwa krzyżackiego pochodziła prawdopodobnie również z obszarów Górnej Saksonii, Turyngii i być może także Śląska. Po przybyciu do Elbląga garncarz wzbogacił swój asortyment naczyń o takie, które były znane być może mniejszej grupie mieszkańców - charakterystyczne dla terenów północnych Niemiec.

Materiał odkryty w obrębie pieca garncarskiego jest kolejnym doskonałym przykładem, że przynajmniej w przypadku Elbląga niekiedy bardzo trudno przeprowadzić rozgraniczenie na „lokalne” i „obce”, mimo rozpoznania form charakterystycznych dla różnych obszarów, które w tym czasie były także odmienne pod względem językowym. Po raz kolejny widać, że dla mieszkańców Starego Miasta Elbląga pod tymi pojęciami kryły się zapewne różne wytwory elbląskiego 

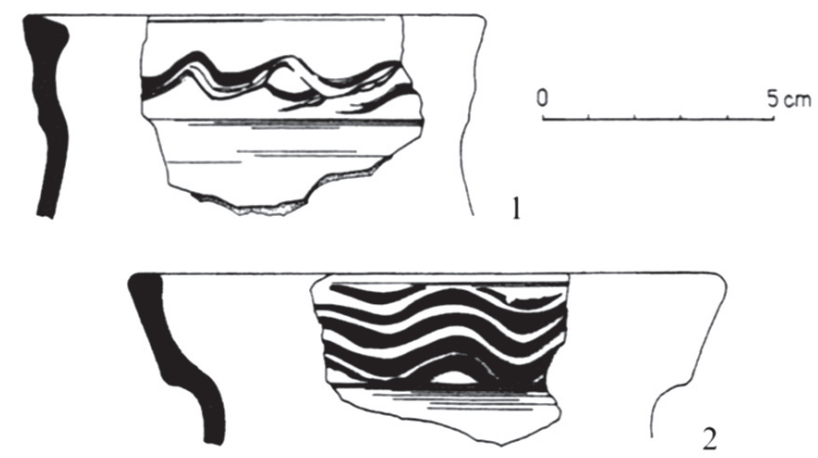

Ryc. 3. Elbląg - Stare Miasto.

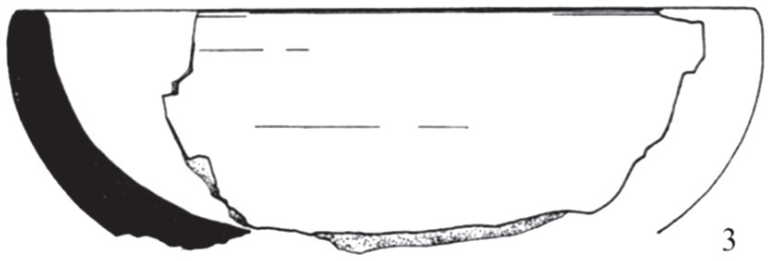

1,2 - dzbany typu VIII; 3, 4 - czasze lamp ceramicznych (rys. B. Kiliński)

Fig. 3. Elbląg-The Old Town. 1,2- - itchers type VIII; $3,4-$ bowls of ceramic lamps (drawing by B. Kiliński)
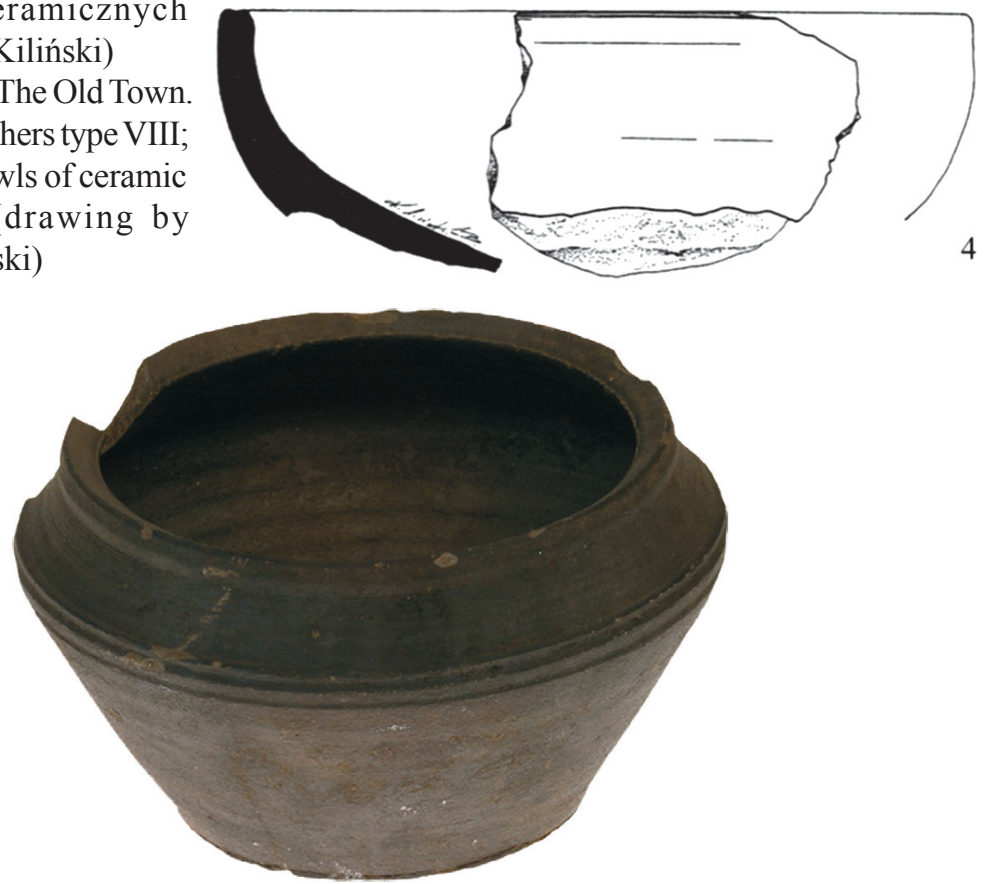

Ryc. 4. Elbląg - Stare Miasto. Misa typu IV (fot. A. Kołecki)

Fig. 4. Elbląg - The Old Town. Bowl type IV (photo by A. Kołecki) 
już przecież rzemiosła. Budujące i rozwijające się miasto i jego mieszkańcy tworzyli nową jakość przez wzajemny wpływ różnych tradycji kulturowych. Było to zresztą zjawisko widoczne także w następnych okresach historii miasta.

Około 100 lat później w elbląskim asortymencie garncarskim pojawiły się naczynia, którym na obecnym etapie badań również trudno przypisać pochodzenie lokalne lub obce. Były to wytwarzane przez miejscowych garncarzy od 2. ćwierci XIV wieku prawdopodobnie od lat 30. tego stulecia naczynia na trzech nóżkach, określane także niemiecką nazwą grapen. Wyroby te mają „garnkowatą" formę, jeden taśmowaty uchwyt oraz mniej lub bardziej zaokrąglone dno z trzema nóżkami (ryc. 5). Ich liczebność wzrosła w 2. połowie XIV wieku, a największą popularność zyskały w XV stuleciu. Trudno wnioskować, jaki wpływ na pojawienie się tych naczyń w asortymencie elbląskich garncarzy miały czynniki zewnętrzne (obce), a jaki lokalne. W rozwiązaniu tego problemu nie pomaga fakt, że w materiale z Kołobrzegu tego typu naczynia (tam zaklasyfikowane do garnków o kulistych dnach) upowszechniły się również w 2. połowie XIV wieku (Rębkowski 1995, s. 29). Być może wpływ na pojawienie, a następnie rozpowszechnienie grapenów miał wzrost liczby mieszczan z warstw dolnej i średniej, pochodzących z Prus i Pomorza Nadwiślańskiego. Według źródeł historycznych właśnie z tych terenów w XIV wieku wywodziła się najliczniejsza grupa mieszczan. W przypadku Elbląga po roku 1350 była to prawie połowa mieszkańców (Czaja, Nawrolski 1993, s. 108). Mniej więcej w tym samym okresie zaczęły wychodzić z użycia inne rodzaje naczyń. Czy jednak pojawienie się nowych wyrobów i zaprzestanie użytkowania innych można łączyć ze zmianami pochodzenia części mieszkańców miasta? Odpowiedź na to pytanie jest bardzo trudna, można jedynie stwierdzić, że oba procesy zachodziły w przybliżonym czasie i być może były ze sobą powiązane.

Na przełomie XV i XVI wieku w elbląskim garncarstwie miała miejsce zmiana technologiczna. Zamiast powszechnie panującego wypału redukcyjnego zaczęto stosować wypał utleniający i pokrywanie szkliwem, najpierw jedynie wewnętrznych powierzchni naczyń. Być może przyjęcie tej nowości odbyło się z zewnątrz, za pośrednictwem ,obcych”, ponieważ w dotychczas odkrytych materiałach ceramicznych z Elbląga brakuje średniowiecznych naczyń szkliwionych pochodzących z miejscowych garncarni. Zjawisko to jest o tyle zastanawiające, że ozdobne szkliwienie cegieł czy innych elementów architektonicznych było stosowane w elbląskim budownictwie monumentalnym już znacznie wcześniej.

Wprowadzenie i upowszechnienie się wypału utleniającego musiało napotykać opory również wśród samych garncarzy, o czym świadczy statut garncarzy malborskich z początku XVI wieku. Został on sporządzony na podstawie podobnych przepisów cechowych wypożyczonych z Elbląga, Gdańska i Tczewa (Pospieszna 1994, s. 279-280). W statucie malborskim znajdziemy zapis zakazujący wytwarzania naczyń siwych pod groźbą kary w wysokości czterech talarów (Pospieszna 1994, s. 282). Można założyć, że podobny znajdował się również w przepisach 

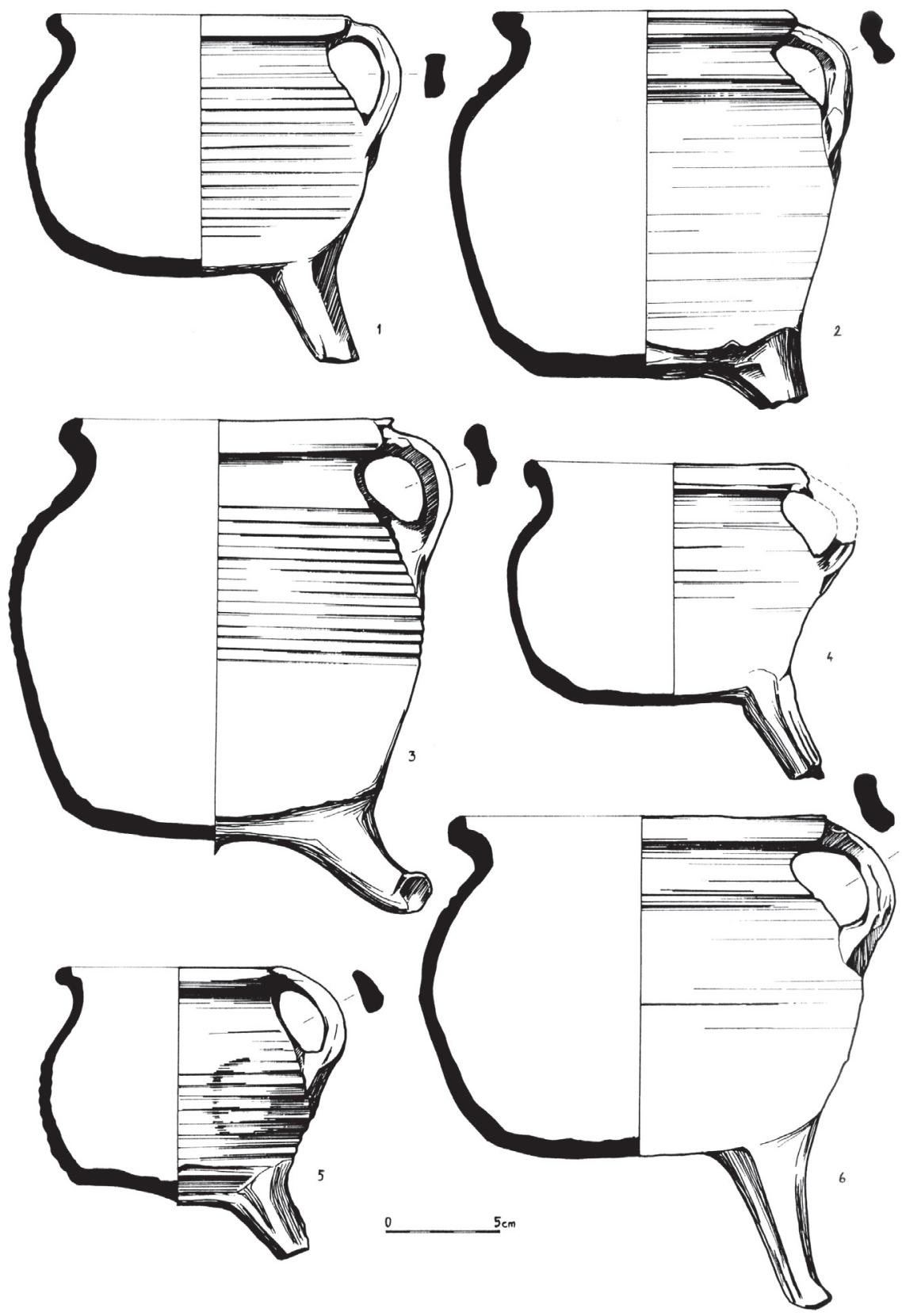

Ryc. 5. Elbląg - Stare Miasto. Grapeny (naczynia na trzech nóżkach), XIV-XV wiek (rys. B. Kiliński)

Fig. 5. Elbląg - The Old Town. Grapens (threepod vessels), $14^{\text {th }}-15^{\text {th }}$ century (drawing by B. Kiliński) 
elbląskiego cechu garncarzy, szczególnie jeżeli weźmiemy pod uwagę bardzo krótki czas współistnienia naczyń siwych i tych zrobionych przy użyciu nowych technologii. Niestety, zupełnie brakuje podstaw do wskazania z jakiego kierunku elbląscy garncarze mogli przyswoić sobie szkliwienie i wypał utleniający. Należy jeszcze zauważyć, że w początkowym okresie musiały one sprawiać sporo trudności. Najstarsze elbląskie naczynia wypalone w technice utleniającej nie są wyrobami ceglastymi i zostały wykonane z zastosowaniem tradycyjnych, średniowiecznych mas garncarskich. Poza tym są to wyłącznie naczynia kuchenne o grubych ściankach, a ich zestaw jest skromniejszy w porównaniu z egzemplarzami siwymi (ryc. 6). W tym samym czasie do użytku weszły również formy wcześniej nieznane elbląskim garncarzom, na przykład flasze (Marcinkowski 2009, s. 152-156). Lepsze przyswojenie nowego sposobu wytwarzania naczyń odnotowano dla końca 1. połowy XVI wieku (Marcinkowski 2009, s. 181).

Również w późniejszym okresie w garncarstwie elbląskim następowała percepcja obcych wzorów stylistycznych i technologicznych. Dotyczyło to kształtu naczyń, motywów zdobniczych, składu masy garncarskiej i technologii wytwarzania. Należy tutaj wymienić naczynia określane jako ceramika biała, ceramika kielecka lub ceramika biała z regionu kieleckiego (Dąbrowska, Gajewska, Kruppé 1993, s. 243; Hadamik 2005, s. 5), charakterystyczne wyroby występujące masowo w XVII-wiecznym materiale elbląskim, a także tym z 1. połowy XVIII wieku. Pod względem technicznym są one wykonane na wysokim poziomie, toczone, a grubość ich ścianek nie przekracza $3 \mathrm{~mm}$, nawet w przypadku największych egzemplarzy. Jednocześnie jest to rodzaj wyrobów garncarskich zdecydowanie wyróżniających się od pozostałych pod względem technologicznym i stylistycznym. Przełamy tych naczyń mają barwę najczęściej jasnoszarą (miejscami prawie białą), niekiedy są wielobarwne - od jasnoszarych do ciemnoszarych, nawet do jasnoceglastych. W niektórych przypadkach rozwarstwiają się, niekiedy widoczne jest łuszczenie się. Czerepy mają barwę od jasnoszarej do jasnosiwej, niekiedy są jasnoceglaste. Wewnętrzne powierzchnie całkowicie pokryte są szkliwem, najczęściej jasnozielonym z ciemniejszymi plamkami. Na zewnętrznych powierzchniach, z wyjątkiem części przydennej, zazwyczaj występuje szkliwo o barwie brązowej, bardzo rzadko ciemnozielonej (Marcinkowski 2009, s. 164-167). Nadal niezbyt dobrze rozwinięte studia nad garncarstwem nowożytnym uniemożliwiają określenie w jakiej części te bardzo charakterystyczne naczynia są miejscowej proweniencji, w jakiej zaś zostały przywiezione z innych ośrodków, w tym także $\mathrm{z}$ rejonu kieleckiego.

Kolejnymi wyrobami wytwarzanymi być może również w elbląskich garncarnich, w odniesieniu do których można wskazać cechy obce i lokalne, są naczynia pokryte na obu powierzchniach jasnobrązowym lub rzadziej zielonym szkliwem dobrej jakości. Przed czynnością tą zostały wykonane charakterystyczne elementy dekoracyjne - medaliony wyciskane w formach i przyklejone do wstępnie 

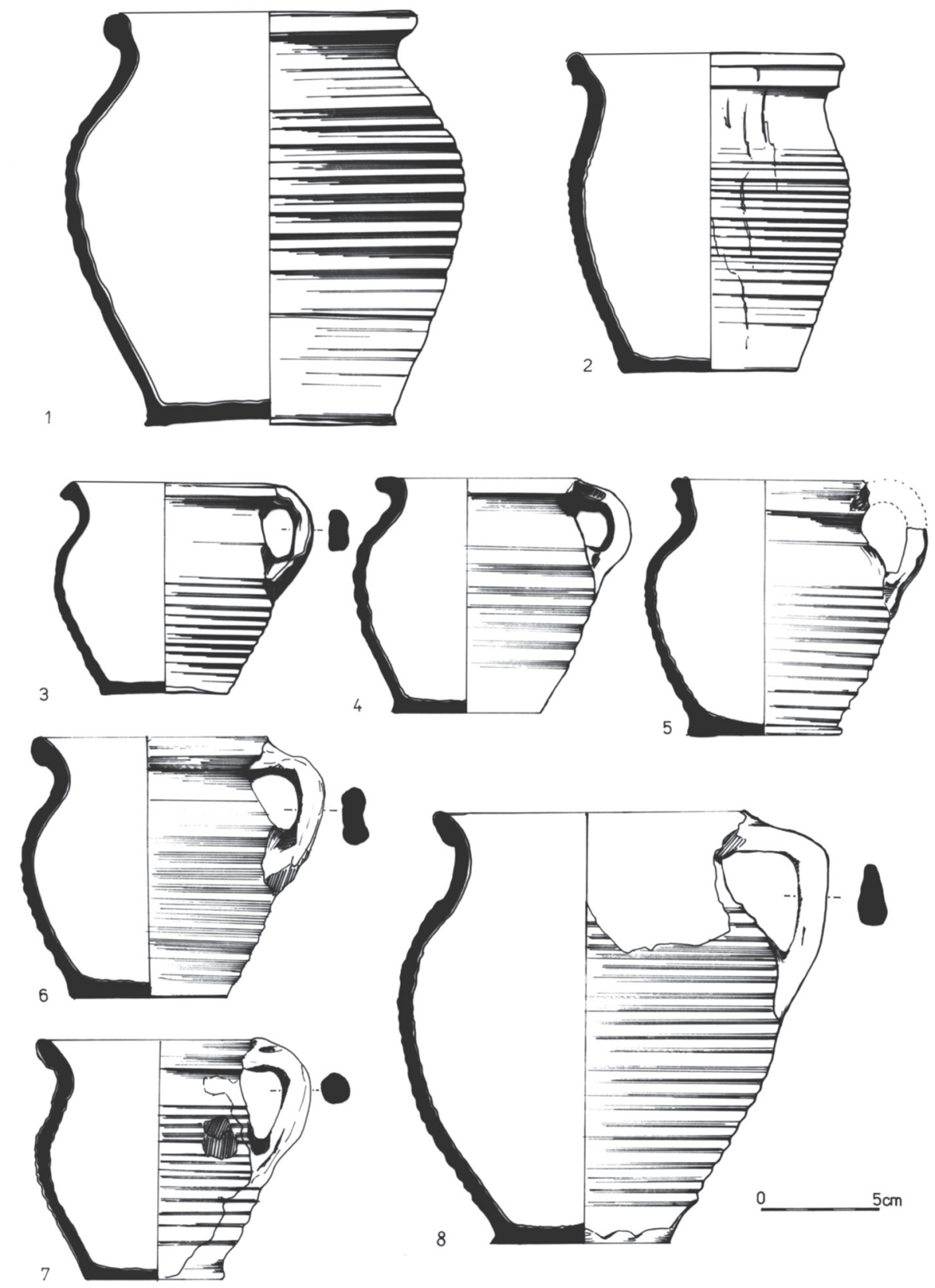

Ryc. 6. Elbląg - Stare Miasto. Formy naczyń, przełom XV i XVI wieku (rys. B. Kiliński) Fig. 6. Elblagg - The Old Town. Forms of vessels, turn of $14^{\text {th }}$ century (drawing by B. Kiliński) 
przesuszonego czerepu, ornament stempelkowy oraz kanelury stosowane na naczyniach naśladujących wyroby kamionkowe. Na medalionach są bardzo różne przedstawienia: postacie ludzi, zwierzęta, motywy roślinne, heraldyczne (dwugłowy orzeł) i inne (głowa lwia, głowa ludzka). Dla wytwórców i użytkowników tych naczyń wymienione elementy miały prawdopodobnie jedynie znaczenie dekoracyjne, bez symbolicznego, o czym świadczą między innymi nakładki na jednym z naczyń. Oprócz wyobrażenia głowy lwa (antaba) i stylizowanych motywów roślinnych widoczne są na nim litery, jednak nie jest to intencjonalny napis, a jedynie ciąg początkowych liter alfabetu: „ABCDEFGH” (ryc. 7) (Marcinkowski 2009, s. 167-169). Chronologię tych wyrobów z Elbląga można określić jedynie dosyć ogólnie. Z całą pewnością były one użytkowane w XVIII wieku, choć nie jest wykluczone, że pojawiły się już na przełomie XVII i XVIII stulecia.

Wyżej podano przykłady, gdzie bardzo czytelne są wpływy obce na lokalną wytwórczość garncarską. Takich problemów badawczych związanych z nowożytnym garncarstwem, a czekających na poznanie jest jeszcze dużo. Można tu chociażby wspomnieć o naczyniach w typie Werra. Niestety, wciąż niezadowalający stan badań nad garncarstwem nowożytnym w Polsce uniemożliwia bardziej szczegółowe prześledzenie tych problemów. Wypada jedynie mieć nadzieję, że pozwoli na to widoczny wzrost zainteresowania tą wytwórczością.

Jednym z lepiej poznanych zagadnień lokalnego garncarstwa nowożytnego w Elblągu są naczynia określane jako fajans pomorski. Dlatego w tym przypadku wskazanie cech lokalnych i obcych, zarówno w odniesieniu do technologii, jak i dekoracji, jest znacznie łatwiejsze. Fajans pomorski miejscowi garncarze rozpoczęli wytwarzać być może jeszcze pod koniec XVII, a na pewno na początku następnego stulecia. Naczynia charakteryzują się porowatym, jasnym czerepem, na ich stronę licową nakładano białe szkliwo cynowo-ołowiowe, a następnie wykonywano ornament farbami podszkliwnymi. Niektóre naczynia na koniec pokrywano bezbarwnym szkliwem ołowiowym. W ten sposób robione były najbardziej powszechne rodzaje (typy) naczyń - talerze i misy. Inne, będące w mniejszości, jak formy garnkowe, kufle, naczynia dekoracyjne, lawaterze, były szkliwione na obu powierzchniach.

Niezwykły wzrost popularności wyrobów fajansowych w całej Europie rozpoczął się po połowie XVII wieku. Spowodował to przede wszystkim napływ do Europy, poprzez porty niderlandzkie, porcelany dalekowschodniej; ważnym czynnikiem były też wydarzenia w Delft. Te ostatnie spowodowały, że z miasta znanego z piwa, stało się ośrodkiem słynącym z wytwórczości garncarskiej (Piątkiewicz-Dereniowa 1996, s. 11; Kilarska 2003, s. 13). Upodobania europejczyków do naczyń porcelanowych, na dodatek zdobionych nieznanymi, zapewne także niekiedy ,tajemniczymi” motywami, stały się bodźcem dla ceramików niderlandzkich. Zaczęli oni naśladować wyroby dalekowschodnie, zastępując nieznaną porcelanę fajansem. Wkrótce te naczynia, niekiedy bardzo dobrze 
kopiujące wyroby porcelanowe, a jednocześnie dużo od nich tańsze, zdobyły wielką popularność wśród mniej zamożnej części społeczeństwa europejskiego. Ta moda nie ominęła także Prus i Elbląga.

Masowy napływ tanich wyrobów niderlandzkich był bardzo dużym zagrożeniem dla funkcjonowania miejscowych garncarni. Próby sprostania tej konkurencji wiązały się z poważnymi trudnościami technologicznymi, na przykład brak złóż glin biało wypalających się spowodował konieczność opanowania wyrobu fajansowej masy garncarskiej w inny sposób. Problem ten rozwiązano przez dodawanie do glin żelazistych węglanu wapnia (Marcinkowski 2011, s. 31). Nie jest możliwe stwierdzenie, czy umiejętność zestawiania fajansowych mas garncarskich została opanowana samodzielnie przez miejscowych garncarzy, czy też za pośrednictwem innych ośrodków, być może niemieckich. Mogli $\mathrm{z}$ nią zapoznać się także elbląscy czeladnicy rzemiosła garncarskiego w trakcie obowiązkowych wędrówek.

Znacznie łatwiejsze jest wskazanie źródła zapożyczeń w stosunku do dekoracji wykonywanej na naczyniach (przede wszystkim talerzach i misach). W tym przypadku możemy często obserwować dwustopniowe kopiowanie obcych wzorów. Najpierw dalekowschodnie dekoracje malarskie umieszczano na fajansowych wyrobach holenderskich. Z kolei z nich, przywożonych między innymi do portu elbląskiego, były przenoszone na naczynia wytwarzane w miejscowych garncarniach. Jednym z najbardziej charakterystycznych jest motyw „chińskich rezerw", umieszczany na kołnierzach talerzy (ryc. 8). W pierwowzorach dalekowschodnich, wykonanych w stylu Wan-Li (nazwa pochodzi od ostatniego cesarza dynastii Ming, panującego w latach 1573-1619), były to symboliczne motywy chińskie, między innymi ze znakami szczęścia (Kilarska 2003, s. 55). Dla kopiujących je malarzy europejskich stanowiły jedynie motywy geometryczne. Dlatego też ich odwzorowanie, szczególnie na wyrobach z fajansu pomorskiego, bywa jedynie zbliżone do oryginału, niekiedy w niewielkim stopniu przypominające te malowane na chińskich pierwowzorach. Na niektórych talerzach z fajansu pomorskiego widać wprowadzane przez lokalnych malarzy modyfikacje dekoracji - w polach rezerw umieszczone są drobne kwiaty tulipanów (Marcinkowski 2011, s. 55-58). Swoista „tulipomania” zapanowała głównie w Holandii, gdzie cebulki tych kwiatów potrafiły być źródłem bogactwa, ale też i krachu finansowego wielu ludzi (Herbert 2003, s. 39-59).

Innym przykładem niemal wiernego kopiowania dekoracji, jedynie z drobnymi zmianami, są duże talerze $\mathrm{z}$ fajansu pomorskiego $\mathrm{z}$ umieszczoną na nich tzw. sceną ogrodową (Marcinkowski 2011, s. 61-66). Widoczne na niektórych egzemplarzach daty pozwalają określić, że miejscowi garncarze ten sposób zdobienia preferowali w latach 40. XVIII wieku. W centrum dekoracji zwykle widoczne są dwie lub trzy postaci ludzkie, odziane w szaty naśladujące dalekowschodnie pierwowzory. $\mathrm{Z}$ lewej strony znajduje się wysokie drzewo, najczęściej z trzema konarami 
(na wyrobach porcelanowych były to drzewa herbaciane). W tle, u góry widnieją wzniesienia i budynki z charakterystycznymi wygiętymi połaciami dachowymi. Z prawej strony dekoracji najczęściej malowano tzw. zasłony, czyli trójkątne pasy pokryte różnymi odcieniami kobaltu. Całość kompozycji uzupełniają motywy roślinne, niekiedy elementy małej architektury ogrodowej - balustrady i schody (ryc. 9). Wszystkie dotychczas znane talerze prezentują wysoki poziom biegłości malarskiej i wykonane są jedynie barwnikiem kobaltowym. Miejscowi malarze ceramiki za wzory do sowich scen niewątpliwie obrali wyroby z pracowni holenderskich, a przede wszystkim z Delft. Z dużym prawdopodobieństwem możemy nawet wskazać konkretny warsztat, którym był „Die Vergulde Astronnekens” Gerita Pietersz Kama z lat 1679-1705 (Kilarska 2003, s. 61-64, kat. 26-30). Przemawia za tym bardzo podobny, niekiedy wręcz identyczny program scen ogrodowych oraz zbliżony sposób ich malowania. Naczynia z podobną dekoracją były wykonywane także w innych ośrodkach, na przykład we Frankfurcie (Riesebieter 1921, ryc. 30) i Hanau (Zeh 1978, ryc. 13-15, 17, tabl. XIV). Jednak program ich dekoracji różni się od pochodzących z Delft i Prus Królewskich.

Podane wyżej dwa przykłady podwójnego naśladownictwa dekoracji malarskich (najpierw z naczyń porcelanowych na fajanse holenderskie, a następnie na fajanse pomorskie) nie są jedynymi. Szczególnie w 1. połowie XVIII wieku niemal wyłącznie kopiowano wytwory obcego rzemiosła ceramicznego, przypływające do elbląskiego portu. Po połowie stulecia również powielano określone sposoby dekoracji czy pojedyncze motywy, jednak rzadko są już one tak ewidentne, najczęściej trudno jest określić bezpośrednie analogie. Znacznie łatwiej można wskazać inspiracje, wykorzystanie pojedynczych motywów dekoracyjnych czy określić podobieństwo.

Do wyjątków należy bardzo często występujący na talerzach datowanych na 2 . połowę XVIII wieku tzw. motyw tataraku lub zamkniętej gałązki, niemal wiernie przeniesiony z talerzy holenderskich, licznie przywożonych do portu elbląskiego przynajmniej od lat 70. XVII wieku (ryc. 10) (Marcinkowski 2011, s. 86). Ten sam motyw dekoracyjny był w XIX wieku wykorzystywany do zdobienia tzw. ceramiki kaszubskiej; określany jest „wiankiem kaszubskim” i uznawany za jeden z najstarszych motywów na tych wyrobach (Krajewska 1958, s. 225). Można przypuszczać, że przynajmniej w niektórych przypadkach dla garncarzy kaszubskich inspiracjami i wzorcami dekoracji były wcześniej wytwarzane naczynia z fajansu pomorskiego. Prawdopodobnie mamy do czynienia z przejęciem mody i wzorów panujących w środowisku miejskim do środowiska wiejskiego i małomiasteczkowego. Tym bardziej, że tereny na których wytwarzana była ceramika kaszubska sąsiadują z obszarem, gdzie produkowano naczynia $\mathrm{z}$ fajansu pomorskiego.

Zaprezentowane wyżej naczynia ceramiczne potwierdzają tezę, że cechy czy wpływy obce są doskonale czytelne w lokalnej wytwórczości. Wśród wyrobów elbląskiego rzemiosła garncarskiego można wskazać dużo więcej takich przykładów. 


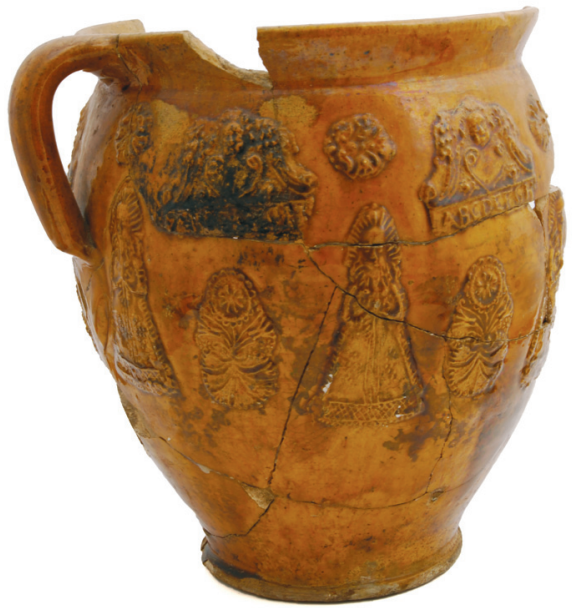

Ryc. 7. Elbląg - Stare Miasto. Naczynie z nakładkami ceramicznymi (fot.

A. Grzelak)

Fig. 7. Elbląg - The Old Town. Vessel with ceramic tops (photo by A. Grzelak)

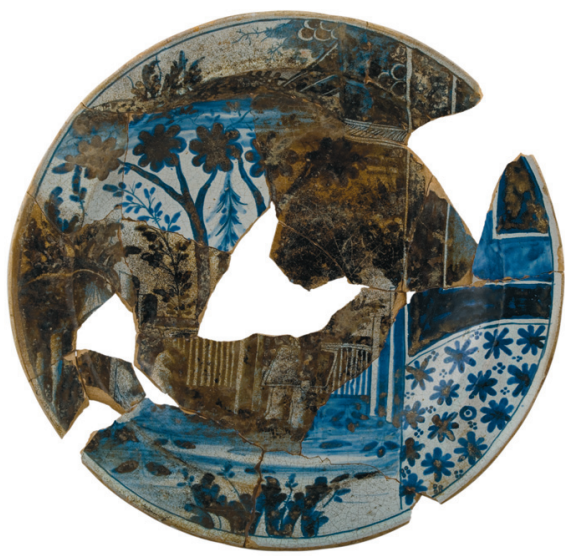

Ryc. 9. Elbląg - Stare Miasto. Talerz ze sceną ogrodową, lata 40. XVIII wieku (fot. A. Czuba)

Fig. 9. Elbląg - The Old Town. Plate with a garden scene, the 40 s of $18^{\text {th }}$ century (photo by A. Czuba)

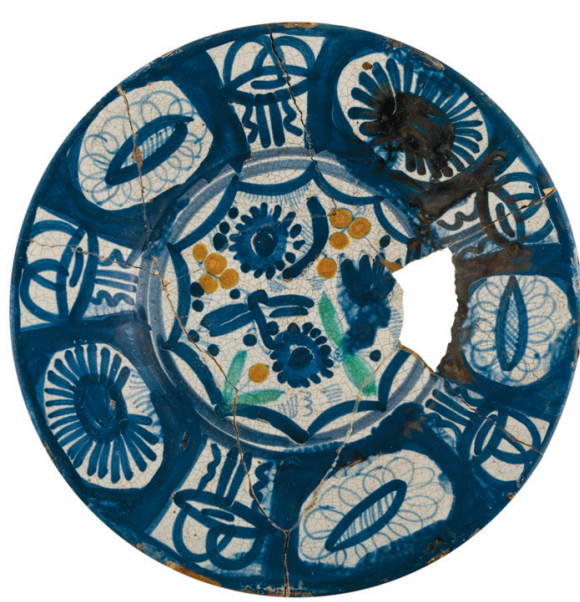

Ryc. 8. Elbląg - Stare Miasto. Talerz z chińskimi rezerwami na kołnierzu, 1. połowa XVIII wieku (fot. A. Czuba)

Fig. 8. Elbląg - The Old Town. Plate with Chinese reserves on the rim, $1^{\text {st }}$ half of $18^{\text {th }}$ century (photo by A. Czuba)

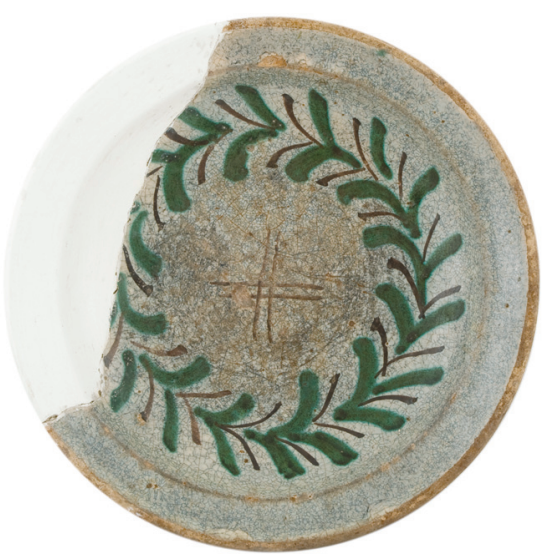

Ryc. 10. Elbląg - Stare Miasto. Talerz z dekoracją zamkniętej gałązki (gałązki tataraku), 2. połowa XVIII wieku (fot. A. Czuba)

Fig. 10. Elbląg - The Old Town. Plate decorated with closed branch (sweet flag), $2^{\text {nd }}$ half of $18^{\text {th }}$ century (photo by A. Czuba) 
Ich analiza pozwala na prześledzenie i rozpoznanie wielu aspektów kulturowych, nie tylko związanych z rzemiosłem garncarskim. Wskazują, że najbardziej powszechny materiał archeologiczny jest doskonałym źródłem przydatnym do rekonstrukcji minionej rzeczywistości. W sprzyjających okolicznościach naczynia lub ich fragmenty mogą nawet wskazać pochodzenie etniczne mieszkańców, służyć do prześledzenia wpływów kulturowych czy kierunków wymiany handlowej.

\section{Literatura}

Dąbrowska M., Gajewska M., Kruppé J.

1993 Późnośredniowieczne i nowożytne naczynia gliniane oraz kafle. Komentarz do analizy, [w:] Sandomierz. Badania 1969-1973, t. 1, red. S. Tabaczyński, Warszawa, s. 240-261.

Czaja R., Nawrolski T.

1993 Pierwotny Elblag, [w:] Historia Elblaga, t. 1: Do 1466 r., red. S. Gierszewski, A. Groth, Gdańsk, s. 60-130.

Hadamik C.

2005 Wstep, [w:] Naczynia białe w Polsce południowej i środkowej. Wstęp do problematyki badawczej, red. A. Buko, L. Kajzer, Kielce-Lagów, s. 5-7.

Herbert Z. 2003 Martwa natura $z$ wędzidlem, Warszawa.

Hübner W.

1959 Die Keramik von Haithabu. Die Ausgrabungen in Haithabu 2, Neumünster. Janssen W.

1966 Zur Typologie und Chronologie mittelalterlich Keramik aus Südniedersachsen, Neumünster.

Kilarska E.

$2003 \quad$ Fajanse z Delft w dawnym Gdańsku, Gdańsk.

Krajewska J.

1958 Ceramika kaszubska z końca XIXi poczatku XX wieku (Zakończenie), Polska

Sztuka Ludowa, R. 12, nr 4, s. 215-238.

Kropidłowski Z.

1977 Samopomoc w korporacjach rzemieślniczych Gdańska, Torunia i Elblaga (XIV-XVIII w.), Gdańsk.

Lüdtke H.

1985 Die mittelalterliche Keramik von Schleswig. Ausgrabung Schild 1971-1975, Ausgrabungen in Schleswig, Berichte und Studien, t. 4, Neumünster.

Madsen H. J.

1971 Keramik, [w:] Arhus Søndervold, København, s. 64-105.

Maik J.

2005 Tekstylia z tzw. domu rybaka w Elblągu, maszynopis w Muzem Archeologiczno-Historycznym w Elblągu, Łodź. 
Marcinkowski M.

2003 Średniowieczny warsztat garncarski ze Starego Miasta w Elblagu, Pomorania Antiqua, t. 19, s. 193-250.

2006a Wytwórczość garncarska w Elbląu (na podstawie wybranego zbioru). Część 1 -średniowiecze (1237-przełom XV i XVI wieku), Pomorania Antiqua, t. 21, s. 271-342.

2006b Dom poławiacza jesiotrów z połowy XIII wieku na Starym Mieście w Elblagu, [w:] Nie tylko archeologia. Księga poświęcona pamięci Eugeniusza ,, Gwidona" Wilgockiego, red. E. Cnotliwy i in., Szczecin, s. 235-249.

2009 Lokalna wytwórczość garncarska w Elblagu (na podstawie wybranego zbioru). Część 2 - okres nowożytny (XVI-XIX wiek), Pomorania Antiqua, t. 22, s. $147-214$.

2011 Fajans pomorski ze Starego Miasta w Elblagu, Elbląg.

Mechelk H. W.

1981 Zur Frühgeschichte der Stadt Dresden und zur Herausbildung einer spätmittelalterlichen Keramikprodukten im sächsischen Elbegebiet aufgrund archäogischer Befunde, Berlin.

Niegoda J.

1999 Naczynia ceramiczne, [w:] Ze studiów nad życiem codziennym w średniowiecznym mieście. Parcele przy ulicy Więziennej 10-11 we Wrocławiu, Wratislavia Antiqua 1, red. C. Buśko, J. Piekalski, Wrocław, s. 157-182.

Piątkiewicz-Dereniowa M.

1996 Fajanse z Delft w zbiorach Zamku Królewskiego na Wawelu, Kraków.

Pospieszna B.

1994 Zarys historii rzemiosła zduńsko-garncarskiego w Malborku, od wieku XVdo poczatku XIX, [w:] Garncarstwo i kaflarstwo na ziemiach polskich od późnego średniowiecza do czasów nowożytnych. Materiały z konferencji-Rzeszów 21-23 IX 1993, red. A. Gruszczyńska, A. Targońska, Rzeszów, s. 276-290.

Riesebieter O.

1921 Die deutschen Fayencen des 17. und 18. Jahrhunderts, Leipzig. Rębkowski M.

1995 Średniowieczna ceramika miasta lokacyjnego w Kołobrzegu, Kołobrzeg. Stadt Archäologie

1984 5 Jahre Stadt Archäologie. Das neue Bild des alten Göttingen, red. S. Schütte, Göttingen.

Zeh E.

1978 Hanauer Fayence. Ein Beitrag zur Geschichte die deutschen Keramik, Hanau am Main. 


\section{FOREIGN AND LOCAL FEATURES IN MEDIAEVAL AND MODERN ELBLĄG CERAMICS. PROBLEM OUTLINE ON THE BASE OF SELECTED EXAMPLES}

Summary

The article touches the problem of foreign and local features' identification distinguished in Elbląg pottery craft. In case of mediaeval vessels it is difficult to state, which characteristics can be regarded as foreign and which are prescribed to local tradition, what is a direct consequence of various ethnic and geographical origin of the town inhabitants.

Technologically and stylistically the oldest vessels include the examples defined as traditional. They differ clearly from predominating grey products, characteristic for the settlers coming from German territories.

Characteristic features describing North German and Middle German workshops are clearly readable in case of vessels originating from one collection - pottery kiln dated from the $70 \mathrm{~s}-80 \mathrm{~s}$ of $13^{\text {th }}$ century. In majority of cases they enable to identify vessels produced there with the terrains of the Upper Saxony and Thuringia, to a lesser extent with the area of northern Germany.

First half of $14^{\text {th }}$ century is the period when Elblag vessel assortment is enriched by examples of treepod vessels, earlier not produced by local potters. At the turn of $15^{\text {th }}$ century, Elbląg craftsmen began to kiln their products in oxidizing atmosphere and coat them with glaze (initially only from the inside). At present it is difficult to state if these two novelties were accepted by the means of foreign influences or they were the results of local factors.

Elbląg modern pottery displays foreign impacts - in technology and the mode of decorating, which is seen evidently in case of dishes defined as Pomeranian faience. Elbląg potters, and generally Prussian craftsmen, not wanting to be pushed off by Delft competitors, learned the way of faience vessels production and accepted their way of decorating. In the first stage, i.e. in $1^{\text {st }}$ half of $18^{\text {th }}$ century, they were nearly solely 'Chinese' motifs, copied from Far East porcelain, first by Netherland painters and next the ones from Prussia. In $2^{\text {nd }}$ half of that century, Far East motifs are met rather rarely, although imitating patterns of Netherland ceramics is still visible.

These few examples indicate univocally that foreign and local features are clearly observable not only in case of imports, but also in local craft products, although it is difficult sometimes to state evidently which of them and for which social group they were foreign and which local. 
